PRESENT STATUS OF THE RAILWAY TECHNICAL RESEARCH INSTITUTE AND SEISMIC

RESEARCH AND DESIGNING IN THE JAPANESE NATIONAL RAILWAYS

Tatsuo Nishiki, D. Eng. *

As Director of the Railway Technical. Research Institute, JNR, I deem it a great honour to contribute an article to your esteemed Bulletin, about the present status of this Institute and about the latest developments in seismic research and designing in JNR.

\section{OUTLINE OF RTRI}

The Rallway Technical Research Institute is ccunted as one of the most important organisations in JNR. For 63 years since its founding in 1907 it has played a leading role in the progress of railway engineering. Its activities range from comprehensive investigations and tests related to the land transport to technical information service, scientific and engineering calculations and technical consultations to the whole JNR.

At the top of the list of latest achievements comes the inauguration of SHIN KANSEN which embodies numerous results of research and testing carried out at RTRI.

Success of SHIN KANSEN has made the people freshly recognize the significance of railway as the only dependable means of mass land transport. It is obvious, however, that the railway will not be able to survive in the twenty first century as an efficient means of transport unless it outgrows the present SHIN KANSEN into a more advanced form. JNR is now in a financial distress and the policy of "structural reform of JNR into a high-productivity modernized means of transport" is being stressed to get out of this as well as for future survival.

It goes without saying that positive development and introduction of new technology are indispensable for modermization of JNR. RTRI plays a most vital role in the forefront of railway modernization along the lines of long-range technical development laid down by the Head Office of JNR.

Next, description will be made of the position of RTRI in JNR and its internal organization. Figure $I$ is an organizational chart of JNR, and Figure 2 shows the internal organization of RTRI, which comprises 3 Departments, 3 Centres and 34 Laboratories. The three Departments are Administrative Department, Maintenance \& Shop Department and Research Planning Department. The three Centres are Technical Information Centre, Electronic Computer Centre and Measuring Instrument Centre. The 34 Laboratories are placed under direct

* Director of the Railway Technical Research Institute, JNR control of Director instead of being grouped into divisions. The personnel totals about 840 , of which over 650 work in laboratories. In 1969 the Institute spent about 2800 million for its activities.

For 1970, about 360 research items are assigned to the laboratories. Railway engineering is a composite technology ranging over different areas of learning; and depending on the contents of work, a project may extend beyond the scope of a single laboratory. In that case the research efforts are pooled in a project team made of research members recruited from several laboratories closely related to the project.

The group study projects to be vigorously pushed this year are as follows:

- Establishment of automatic system for ticket issuing and inspection system.

- Comprehensive investigation for speedup on narrow-gauge lines.

- Establishment of pipe line transport system.

- Development of COMTRAC for SAN-YO SHIN KANSEN.

- Improvement of ballastless track structure.

- Countermeasure for contamination of ballast.

- Feeding system with auto-transformer.

- Countermeasure for mid-run derailment of freightcars.

- Establishment of automatic system for Musashino freightyard.

- Automation of train operation control.

- Development of high-efficiency tunnelling ari11.

In addition to the above, there are the following research items ranking in the preproject stage which call for steady efforts in group study by different experts from wide areas of technology:

- Mechanization of baggage and parcels handling.

- Passenger information processing.

- Evaluation of freight transport systems.

- Economical concrete ties and fastenings.

- Countermeasure for thyristor trouble.

- Countermeasure for ground vibration.

- Seismic damage survey.

- Improvement of current-collection materials.

- Improvement of brake performance.

- Prevention of rail failure accident.

- Prevention of wheel axle failure accident.

- Drive and suspension system for superspeed railway.

- Guideway system for superspeed railway.

- Snow fighting measures for the nation wide network of SHIN KANSEN.

- Running resistance of high speed train. 


\section{SEISMIC RESEARCH AND DESIGNING}

Seismological investigation in JNR is undertaken by RTRI. Aseismic designing of structures is entrusted to the Structure Design office (see Figure 1).

Earthquake problems mainly related to railway are handled by research staff of the Laboratories : Structure, Soil Mechanics, Geology, Architecture and Disaster Prevention. Emphasis in their activities is laid on train operation safety in relation to earthquake and on modernization of aseismic designing of railway structures. To mention a few examples of their recent studies, there are:

Relation between earthquake and bridges, subgrade of embankment, relation between seismic damage to railway and geology and damage prevention, dynamic characteristics of soil and aseismic designing of structures.

In 1963 the Structure Design Office drafted the Structure Design Basic Provisions which provide basis to the designing of civil engineering structures in JNR; and in April 1970 it has drastically revised these provisions with addition of subsequent developments in research. Meanwhile it has also formulated a detailed procedure of structure designing. At the same time it has established a new Structure Design Standard (for steel railway bridge, reinforced and non-reinforced concrete structures and prestressed concrete railway bridge).

Stipulations about aseismic designing are included under all these rules and in accordance with these stipulations, constructions and reconstructions of tracks on SHIN KANSEN and narrow-gauge lines are actually being designed.

Every time an earthquake shock attacks, a survey team is organised to make full investigations of damage to railway structures.

Technical research projects undertaken by JNR since 1960 about earthquakes are as follows:

(1) Study on aseismic desiğn method (1960 $1964)$

(2) Study on optimum seismic coefficient for building (1960 - 1961)

(3) Study on aseismic designing of bridge substructure in a weak ground (1965 1967)

(4) Study on track stability under earthquake $(1965$ - 1967)

(5) Study on aseismic designing of bridge substructure with due consideration of seismic response (1968 - 1970)

(6) Study on aseismic designing of embankment on weak ground (on aseismic designing of earth structures on SHIN KANSEN) (1969 1970)

(7) Study on designing of concrete structures subjected to seismic load (1970)

The following is a list of reports published so far since 1943 about earthquake studies :

1. M. Uchiyama et al.: Report on the Earthquake Damage in Tottori District, Report RTRI 2nd Div., 1943 -- in Japanese --

2. M. Saito et al.; Report on Damage to West Kisei Line due to Nankai Earthquake. Dec. 21, 1946, 1947 -- in Japanese --

3. T. Suzuki et al.; Report on the Fukui
Earthquake June 28, 1948, Report RTRI, 2nd Div., 1948 - in Japanese --

4. JNR; Study on the Design Seismic Coefficlent for Buildings - A New Treatise for High Rise Buildings, Report for Technical Research Project, JNR, 1962 -- in Japanese --

5. M. Ihara, C. Ueda, M. Tamura, K. Ono; Lateral Loading Test on Former Hamamatsu Railway Hospital Buildings, RTRI-Pre Report. No. 63-104, 1963,4 -- in Japanese --

6. M. Ihara, C. Ueda, M. Tamura, K. Ono, Y. Ochi, I. Tachibana; Lateral Loading and Vibration Test on Former Maibara Rolling Stock Inspection Office Building, RTRIPre Report No. 63-152 1963, 6 -- in Japanese --

7. Y. Tada et al.; Report of Survey of the Niigata Earthquake, Report RTRI No. 448 , 1964 -- in Japanese --

8. M. Ihara, C. Ueda, M. Tamura, K. Ono: Breaking Down Characteristics of Existing Steel Framed Reinforced Concrete Structure - Former Strength Testing Laboratory of RTRI, JNR RTRI Report No. 412, May 1964 -- in Japanese --

9. JSCE; Study on Aseismic Designing of Bridge Substructure in a Weak Ground, 1965

Ditto, 1966

Ditto, 1967 -- in Japanese --

10. T. Fujiwara; on Seismometers Setting in in Borehole of Seto Inland Sea of Japan, RTRI Report No. 572, Jan. 1967 -- in Japanese --

11. Sumitomo Construction Co. Ltd.; Report of Ultimate Strength Test of Prestressed Concrete Beam and Column Joints - The Case of Body Repair Shop of the Ohi Workshop, JNR, Report supplied to Tokyo Building Construction Office, JNR, 1967 -- in Japanese --

12. T. Nishiki; Rationalization of Structure of Concrete Bridge Against Earthquake, Japanese Railway Engineering, Sept. 1967, Vol. 8, No. 3 .

13. G. Yamad et al.; Report of Damage to Railways in the Tokachioki Earthquake May 16, 1968, Report RTRI No. 650 -- in Japanese --

14. JSCE; Study on Aseismic Designing of Bridge Sub-structure with Due Consideration of Seismic Response, 1968 -- in Japanese --

15. Y. Kobayashi; Mechanism of Earthquake Damage to Embankments and Slopes, Quarterly Report RTRI, Vol. 9 No. 3, 1968.

16. JSCE; Earthquake Resistant Design for Civil Engineering Structures, Earth Structures and Foundations in Japan 1968.

17. Railway Civil Engineers Association; Investigation on the Earthquake Damage to the Tichoku Line in the Off-Tokachi Earthquake, Mar sh 1969, -- in Japanese --

18. Y. Sato, S. Kobayashi, M. Nagata; Study of Track with Concrete Ties and Crushed Stone Ballast in Earthquake, RTRI-Report No 675, Apr. 1969 -- in Japanese --

19. T. Nishiki, K. Tamura, N. Nonogaki; Control of Train Operation on the New Tokaido Line on the Occasion of Earthquake, Proc. 4 WCEE 1969 Session A-2.

20. C. Ueda; Earthquake Vibration Test for the $1 / 25$ Scale Model of 17 staried Building, Proc. 4 WCEE 1969 Session B-3.

21. Y. Kobayashi; Mechanism of Earthquake Damage to Embankments and Slope, Proc. 4 
WCEE 1969 Session B-3.

21. Y. Kobayashi; Mechanism of Earthquake Damage to Embankments and slope, Proc. 4 WCEE 1969 Session A-5.
22. T. Ikehara; Damage to Railway Embankments due to the 1968 TOKACHI-OKI Earthquake, Soils and Foundations, Vol. 10, No. 2. 1970. 
Fig.2. ORGANIZATION

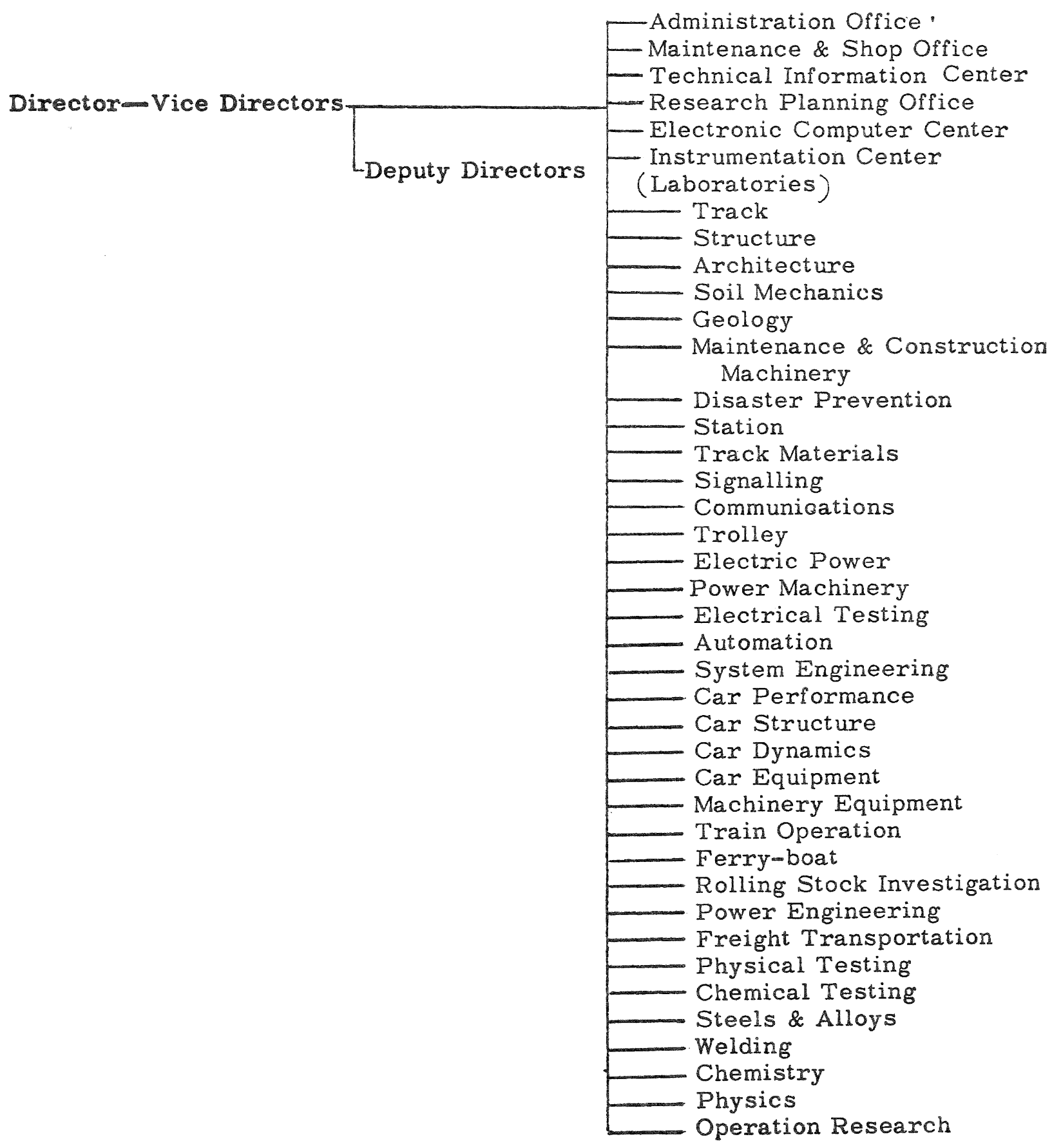




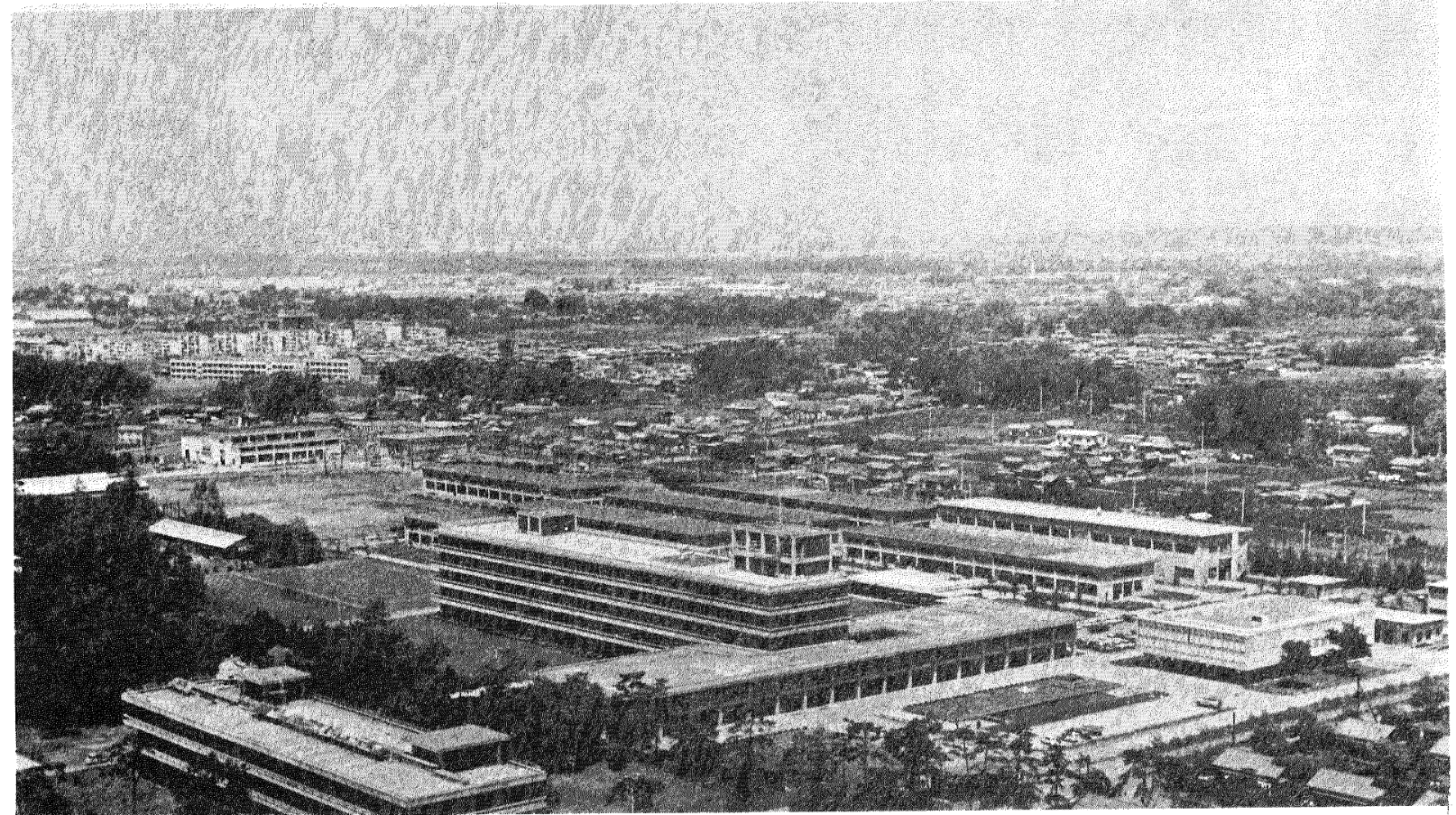

Tokyo scene.

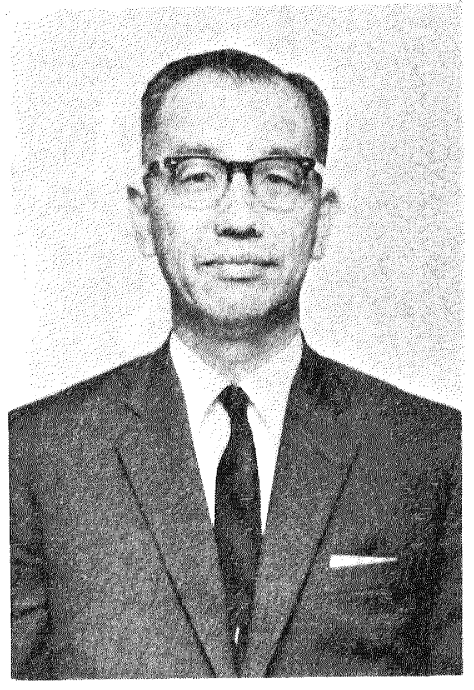

Dr. Tatsuo NISHIKI Director 